\title{
Care management instruments used by nurses in the emergency hospital services*
}

\author{
Instrumentos de gestão do cuidado utilizados por enfermeiros \\ no serviço hospitalar de emergência \\ Instrumentos de gestión del cuidado utilizados por enfermeros \\ en el servicio hospitalario de emergências
}

How to cite this article:

Rabelo SK, Lima SBS, Santos JLG, Santos TM, Reisdorfer E, Hoffmann DR. Care management instruments used by nurses in the emergency hospital services. Rev Esc Enferm USP. 2021;55:e20200514. doi: https://doi.org/10.1590/1980-220X-REEUSP-2020-0514

\section{Simone Kroll Rabelo ${ }^{1}$ \\ Suzinara Beatriz Soares de Lima² \\ José Luís Guedes dos Santos ${ }^{3}$ \\ Tanise Martins dos Santos ${ }^{1}$ \\ Emilene Reisdorfer ${ }^{4}$ \\ Daniela Rodrigues Hoffmann ${ }^{1}$}

* Extracted from the thesis "Processo de trabalho do enfermeiro no Serviço Hospitalar de Emergência”, Programa de

Pós-Graduação em Enfermagem, Universidade Federal de Santa Maria, 2018.

${ }^{1}$ Universidade Federal de Santa Maria, Programa de Pós-Graduação em

Enfermagem, Santa Maria, RS, Brazil.

${ }^{2}$ Universidade Federal de Santa Maria, Departamento de Enfermagem, Santa Maria, RS, Brazil.

${ }^{3}$ Universidade Federal de Santa Catarina, Departamento de Enfermagem,

Florianópolis, SC, Brazil.

${ }^{4}$ MacEwan University, Faculty of Nursing,

Department of Professional Nursing and Allied Health Edmonton, Alberta, Canada.

\section{ABSTRACT}

Objective: To describe the instruments used by nurses for the management of care in face of the demands of the emergency hospital service. Method: This is a qualitative study, with triangulation of data from interviews, focus groups, and documents, conducted with nurses from an Emergency Hospital Service in a state in southern Brazil. Data were subjected to thematic content analysis. Results: Seventeen nurses participated in the study. The categories emerging from this study were view of the whole picture, definition of priorities, and physical instruments. These instruments are used by nurses to manage multiple tasks and provide adequate care to patients with different levels of complexity, in the face of an intense and unpredictable work process due to the constant demand for care. Conclusion: The instruments used by nurses in their work process are mainly skills and attitudes developed as a coping strategy at an intense and complex work environment.

\section{DESCRIPTORS}

Emergency Nursing; Nursing Process; Health Management; Emergency Service, Hospital. 


\section{INTRODUCTION}

Work has become a human need as it has assumed a central role in their life as social beings. It provides the construction of identity and social bonds and a sense of belonging in society. The importance of work changes with the evolution of times, with different historical, social and cultural contexts. Thus, as a consequence, the work foresees a purpose that meets this need ${ }^{(1-3)}$.

Healthcare work is complex and aims at meeting vital needs. Healthcare professionals, at times, may share the same purposes, the same object, but the methods they use are different. The methods are a systematization of actions, used on the object to meet a certain purpose. For this, different instruments are used, which are not only physical and tangible ones, as they also include skills, knowledge, and attitudes that, when combined and focused on a specific situation, determine the way this work will be performed ${ }^{(1)}$.

The growing transformations in health services, especially in the emergency care sectors, promote changes in nursing work. Administrative requirements and needs are increasingly becoming part of the nurses' role. In the midst of the complex reality of the Hospital Emergency Services (SHE), nurses seek to develop their work process with attitudes that demonstrate knowledge, and technical, managerial, and leadership skills ${ }^{(4)}$.

The environment at SHE is challenging, complex, and unpredictable, in which nurses find several obstacles to the development of their work, such as uncertainties regarding the number of patients to be attended during the shift, insufficient resources, and delays in transfers to other sectors ${ }^{(5-6)}$. In this regard, the professionals adapt themselves, molding their work process to the characteristics and adversities, mainly by means of instruments.

Care management is the articulation of the nurses' care and management practice, and shall be an ideal pursued by the professional, as it promotes comprehensive care and provides greater visibility to their practice ${ }^{(7-8)}$. The importance of this work is explained by the belief that nurses, when they become aware of the peculiarity of their work process in the emergency room, increasingly seek clinical skills and management tools to improve their work, with a view to meeting the needs of patients who remain in the service, as well as of those who arrive with urgent demands.

Thus, the objective of this study was to describe the instruments used by nurses for the management of care in face of the demands of the emergency hospital service.

\section{METHOD}

\section{Type OF Study}

This is a study of qualitative, exploratory, and descriptive approach.

\section{LOCAL}

The study was carried out in a highly complex Emergency Hospital Service (SHE), in an inland city of a state in the southern region of Brazil. It is a SHE that responds to the referral demand of medical, surgical, and traumatology clinics of 32 (thirty-two) municipalities. It has 23 (twenty-three) observation beds and an emergency room. The nursing team consists of 20 (twenty) nurses and 48 (forty-eight) nursing technicians. Nurses are distributed in nursing stations: observation hall, corridor, emergency room, and regulation service.

\section{Data Collection}

Data collection took place between August and November 2017. For the selection of participants, the inclusion criterion was a minimum length of service of one year in the unit, and those who were away from work during the period of data collection were excluded.

The complexity and variety of actions developed, as well as the work dynamics, led to the need for multiple perspectives on the object of study. Thus, data were obtained through document analysis, open interviews, and a focus group, with data triangulation being performed ${ }^{(9)}$.

The individual interviews were opened and started with a sociodemographic questionnaire, followed by the guiding question "Tell me about your daily life in the Emergency Service, how is your work process?", and lasted an average of 37 minutes.

The focus group scripts were planned based on the recurrent themes in the interviews, and the aim was an in-depth analysis of the object of study; thus, after a pre-analysis of the interviews, themes for the debate were listed, introduced through a central question. Four meetings were held with an average duration of 60 minutes, with the participation of three nurses on average. At the last meeting, a summary of the preliminary results of the previous groups was presented and their validation was carried out. The meetings were conducted by a moderator and observed by three drafts people.

To obtain secondary data, documentary research was carried out to support the understanding of the scenario under study and the variables that interfered in the nurse's work process during the research, and to provide the characterization of the profile and care configuration of the SHE. Therefore, 369 daily censuses of patients were analyzed, which provided data on the patients' movement within the institution, as well as their care needs.

Data for documentary analysis were provided by the hospital's statistical service and consisted of the number of visits, number of hospitalizations, average length of stay, number of discharges, number of transfers, among others. The patients' daily census, on its turn, was issued each shift by the sector department and contained, among other data, the number of patients hospitalized and under observation, their destination, deaths, number of intubated patients.

\section{Data Analysis and Treatment}

Thematic content analysis was used, which is divided into the steps of pre-analysis, material exploration, treatment, and results interpretation ${ }^{(9)}$. To present the data in the individual interviews, the participants were identified with the letter $\mathrm{E}$, 
followed by a specific number; in the focus group, by the acronym GF, followed by the group's order number.

\section{Ethical Aspects}

The study was carried out in accordance with the ethical requirements of Resolution no. 466/12, from the National Health Council, and obtained approval from the Research Ethics Committee through opinion no. 2.121.720/2017.All participants signed a Free and Informed Consent Form to participate in the research.

\section{RESULTS}

Seventeen nurses with an average age of 38 years and an average training time of 12 years participated in the study. The time spent in the sector was an average of 5 years. There was a predominance of women (10). As for professional qualification, one had a master's degree and 14 had a graduate certificate. Of those who had graduate certificates, five were in urgency and emergency.

Based on a Master's thesis whose objective was to analyze the nurse's work process in the SHE, the category "Instruments used by nurses to manage care in the face of the demands of the Emergency Hospital Service" became evident, which originated the subcategories: vision of the whole picture, priority setting, and physical instruments. Below, each one is presented.

\section{View of the Whole Picture}

In the emergency service, the nurse is responsible for the organization, either of the physical space, patient care, or the nursing service. For this, he/she develops a "view of the whole picture", which corresponds to an overview of the environment and the patients' care needs. This instrument is apprehended as the nurse needs to deal with the high demand of patients already absorbed by the system, that is, hospitalized, and those who arrive at the service with acute problems, when the professional, even if he/she does not systematically evaluate the patient, needs to identify his/her care needs. Thus, it becomes an essential skill in the emergency room, which is required since the beginning of professional practice and improves throughout the work period, given the unpredictability of work and the demand for quick decision-making.

You have to be an agile person, you have to be a person who has vision, see priorities, needs (E9).

(...) Even when you don't have so many skills, as soon as you come here, you end up acquiring it over time, because you need to have this vision (E6).

You have to have an eye and we end up developing this feeling of solving the problem, and I think the emergency room has this power of turning the professional more prepared for this, to visit and say: "No, this one, we are going to bring closer to us, this patient has a chance to complicate at night (...)". And this, we develop, I'm sure of that (E8).

The view of the whole picture is also expressed in the professionals' constant state of alertness. These statements, for example, reinforce the nurses' "watchful eye" to identify possible changes or demands from patients:

A patient in the corridor, you pass by at dawn, you already look at the breath (...) (E8).

We already have a little more advanced dynamics, that you can already look at five patients at the same time and see what each one needs, it is different (...) you have other things to do, but you always pass with the 'squinting' eye to the side, observing all patients (E6).

The nursing technician has the role of helping to broaden the nurse's vision. The nursing team assists the nurse in identifying priorities and attending to complications.

You shall have a good team, because even when you make the round at the beginning of the shift, the patient can destabilize, you are one for many, if the technicians don't help you, you can't look at everyone all the time, so the team is important (GF4EA).

(...) I will prioritize who I must attend to, the technicians team see the others and pass only the complications (...) (E3).

According to the documentary analysis, the service received an average of 318 hospitalizations per month in the period studied, with an average occupancy rate of $121 \%$, an average of 52 hospitalized patients per day, and 891.25 monthly emergency visits. This occupancy rate can be considered underestimated, because the total number of available beds is less than the number of real beds, since the calculation considers the agreed capacity of 43 beds, 20 more than the installed capacity, with these extra patients accommodated in the corridor, as reported in the following speech.

We have a limit of stretchers in the corridor, which would be 20 (...) there are 23 in there, but this limit is not respected. So, we rarely have 20 patients in the corridor and 23 hospitalized, we always have more in the corridor (E4).

In this respect, the "view of the whole picture" becomes necessary due to the high demand, along with the agitated characteristic of the emergency work process, which involves the care of patients already absorbed by the service and those who arrive in an emergency with different health needs.

\section{Setting Priorities}

The definition of priorities emerges as an essential tool in the emergency nurse work process; the organization of all the factors that comprise this work aims to assist critical patients in life-limiting situations. Thus, prioritization seems to permeate all actions of this professional.

I see what is urgent first, I list the priorities, this is one of my strategies, and then I follow what I have to do until the end of the shift (E10).

You try to organize yourself, but you go by priorities (...) (E15).

The emergency service maintained a daily average of 4.5 intubated patients, varying between days with none to 10 (ten) intubated patients. Thus, there is an intense work process in which, in addition to emergency demands, there is the high dependency care demanded by the critical patient 
who remains hospitalized in the unit. Thus, there is a need for fast and accurate care that requires the nurse to establish priorities.

Of the 1272 inpatients, 385 were discharged, evidencing difficulty in the patient's outflow, since many had their health problem solved while still in the unit, generating overcrowding and the consequent need to prioritize care.

I base myself on the severity, when there are several things to do, several requests, you go for what is the priority, which is more urgent, some things remain, of course not what is more urgent, the more urgent you do and there it goes (GF1EA).

I have to observe the patients, see who is more serious and start with him/her, I have to establish priorities, as the problem of the one who is more serious is resolved, so we move on to those who are not so serious (E6).

In this way, the nurse combines the "view of the whole picture" with the definition of priorities when he/she needs to list and order care, and he/she is the one responsible for this decision making.

It is to prioritize, to see who needs you most at that moment and to try to do that in the best way in the shortest time possible to continue and serve more people, because everyone in a certain way needs you (...) (E1).

Our look is different, we focus on main things, (...) I think like this: the duties are the same as that of the nurse, wherever hel she is working, but here there is a difference in that sense that we have to prioritize what we are going to do (E3).

You need to have the view of the whole picture, you have to organize, coordinate, delegate whatever is possible, you have to make necessary decisions (GF4EI).

Prioritization, in view of the patient's severity and needs, permeates all the actions of the emergency nurse, who ends up organizing the disposition of patients according to the need for care. It also involves adapting existing physical resources to the patients' demands and needs.

We try to organize the beds for the most critically ill patients or those who require more care, such as bedridden patients, with fractures, the elderly, so we prioritize the beds and then we start placing the others on stretchers (E4).

We have many patients who need to be monitored and we have few cardiac monitors, so we put on the one who is most serious at the moment, so we end up like that, as a nurse, having to make these decisions (E5).

That patient who needs more care, who needs more observation, we bring a little closer to us, to be more attentive (E5).

The provision of nursing care also follows a hierarchy, in which life maintenance care takes priority. Therefore, the nurse prioritizes who will receive care, and what care will be provided first.

I organize myself as follows: care for the most critical patient first, so suctions are prioritized, care for intubated patients comes first (E4).
To have a view of what is a priority, we are going to medicate patients first, which is a priority; we aren't going to leave any patient in pain, we aren't going to delay antibiotics, then we are going to change them, if we can't bathe them, we will at least change the diapers, we won't leave anyone dirty, and there it goes, if there's time, we're going to give the bath. The nurse shall see this, I think, to decide what we are going to do first, because otherwise it becomes a mess, one goes one side, the other goes to the other side, we go crazy (E11).

\section{Physical Instruments}

The continuous flow of patients, the different needs, pathologies, and professionals circulating in the sector, associated with the intense pace of work, lead to the need for instruments of control and organization. Thus, nurses listed several instruments used in daily life that contribute to the organization of work and assist in decision making, shift change report, care map, and patient identification devices.

The shift change report consists of a form in which all patients are listed, their location, and a brief description of the pathology and basic information, such as continuous infusion drugs, the need for oxygen therapy, the use of tubes, among others. This report provides an overview of the sector to the nurse and other members of the nursing team, and is distributed at each shift change, being constantly updated.

We place and specify everything there; this is important to make our work more objective; as there are many things to do, a lot of information, it is difficult for you to keep it all, so basically we receive the shifts' information through this instrument, and it is with its assistance that we mediate all actions, we know more or less what we have to do, there are notes: patients who are intubated (...) (E13).

Something that makes it a lot easier (...) knowing where each one is, a well-updated report, that gives us a direction, you don't know all of them [patients], but you know the name of the person who is there and where more or less the person is. We can have an idea 'oh this one is in bed five, he is fine, he has no oxygen, he does not have an infusion pump, we are going to take him out and bring the one from the emergency room, who is seriously ill, this is a tool that gives a direction (GF2EE).

Due to the number of critically ill patients who require care and managerial demands, nurses reported the use of a care map, also called a checklist. It consists of a script of activities that shall be carried out in each work shift, which is defined at the beginning of the shift and fixed in a visible place, as a form of reminder of the activities to be carried out.

On a sheet I write down all the suctioning I have to do, all the dressings, all the bladder catheter insertions, nasoenteric catheter insertions, all the tubes $X$-rays that I have to evaluate, all the diets that I have to ask for, the patients undergoing tests, I evaluate all fasting patients, I try to list all the patients who need a bath given by the nursing staff, I see those who have a surgical 
procedure scheduled, I write everything, and as I do each one, I check it on the list (E12).

Patient safety is also improved with the use of these tools, since the large amount, the intense pace of work and the troubled environment leave the professional more vulnerable to making mistakes. Thus, the nurse uses some instruments such as identification plates and bracelets, as specified in the statement below.

We try to identify everyone with signs on the wall, there is a report that is the instrument that we update every shift when changing shift, we highlight it well, I inform during shift change: "Hey! There are so many patients with the same name, you have to be careful with that not to give the wrong medication, not to do the wrong procedure". I also inform the secretary: "bey! Be careful when calling the patient for an exam, be aware that the names are the same" (E3)

Identification plates stuck on the wall next to each patient were a measure adopted throughout the institution, providing adequate material for this purpose, and being connected to the need to organize the SHE, being incorporated as tools. These instruments arise from the need for organization, in part, caused by the dubiousness of the scenario with patient care, sometimes in a life-limiting situation, and sometimes in need for long-term care.

\section{DISCUSSION}

The results of this study reinforce that SHE is a dynamic environment with an unpredictable workload, which requires complex tasks in a critical time, prone to countless interruptions and the management of multiple tasks ${ }^{(10-11)}$. In addition, there is a high number of complex patients ${ }^{(11-12)}$, as well as insufficient structure and overcrowding, which contribute to the conformation of an increasingly difficult scenario to control ${ }^{(5-6)}$.

The differentiated dynamics of the emergency service leads to the need to use instruments to assist nurses in their work process, either physical or not, such as knowledge, skills and attitudes, which are combined in a unique way to meet a specific need ${ }^{(1)}$. Thus, the instruments used by nurses are developed from the need to provide care in this peculiar environment.

The first instrument described was the "view of the whole picture", which allows nurses to recognize the needs for organizing the service and caring for patients. This expanded view of assistance was also found in another study ${ }^{(13)}$, which described its role in the care organization with the team.

The development of the view of the whole picture takes place according to the time of work in the sector and is anchored to the clinical knowledge of the emergency nurse, being shaped by contact with the environment, which requires this expanded view to manage their demands. The experience to deal with the peculiarities of the sector, combined with scientific knowledge, manifests itself in the nurse's autonomy for this performance ${ }^{(6)}$.
In this regard, the view of the whole picture still emerges, as a perception of the patients' state and needs even when the nurse is not systematically evaluating $\mathrm{him} / \mathrm{her} \mathrm{r}^{(10-11)}$. Overcrowding, combined with the potential complexity of patients ${ }^{(14-15)}$, leads to unpredictability, in which problems and care needs change quickly ${ }^{(11)}$. The view of the whole picture expresses the constant state of attention and alertness required from the nurse, which reflects the sense of professional responsibility that the nurse has for maintaining life, as these patients are often in inappropriate and difficultto-see places and, even so, demand constant observation.

The study scenario has a high occupancy rate, characterized by the permanence of hospitalized patients due to the difficult outflow, a problem that is addressed in numerous studies $^{(5,10-12,14,16-17)}$. Thus, overcrowding contributes to the cultural conformation of this scenario, influencing the institution of the view of the whole picture.

The nursing team plays an important role, being essential for the view of the whole picture and the management of care for patients in the emergency. The nursing technician has the role of expanding the nurse's view, updating him/her about the patients'status and needs, which is also described in previous research ${ }^{(13)}$.

A study carried out in Iran found that the lack of nursing care is lower when there is more teamwork. The lack of ability to work as a team contributed to the increase in errors and impairs patient safety. Professionals with a positive attitude towards teamwork consider work to be a collective duty and responsibility ${ }^{(18)}$.

Thus, the view of the whole picture is an instrument refined by the nurse's need to manage nursing care in a high demand, complex, and unpredictable scenario under study so as to manage care, being fundamental for the work at the SHE. The permanence of critically ill and highly dependent patients hospitalized in the SHE increases the nurses' workload $^{(14)}$; there is also the constant arrival of patients in the emergency room, also with high complexity ${ }^{(15)}$. Thus, nurses, through their view of the whole picture, use their knowledge and skills to make decisions and prioritize the nursing team actions in service management and in care.

The second instrument used by nurses is the determination of priorities, which involves adapting resources to the patients' needs. The availability of beds and monitors of vital parameters is not enough to meet the demand, so the nurse is responsible for electing the patients who will occupy the beds, usually those who are bedridden, elderly and/or who have greater hemodynamic instability, a result similar to that found in another study ${ }^{(19)}$.

The scarcity and inadequacy of resources is not an exclusively Brazilian reality. Results of a study carried out in a hospital in the United States report the same problem ${ }^{(11)}$. Another study reports the accommodation of patients on ambulance chairs and stretchers in an emergency setting in Taiwan ${ }^{(5)}$.

The complexity of patients in the emergency department requires nurses to make decisions quickly. Professionals shall use technical knowledge, reflecting on their own 
performance, to achieve better results for patients and advance nursing practice in this area ${ }^{(20-21)}$. Viewed in this way, in an attempt to gain control over the environment, the nurse needs to organize the disposition of patients, allocating them in a way to provide better observation and better care ${ }^{(22-23)}$.

Care actions considered essential, such as medication administration, vital signs controls and pain control, have a higher hierarchical level in patient assistance at SHE, another form of prioritization described in this study. Thus, comfort and hygiene care are often last on this scale that prioritizes life maintenance care. However, they are still a concern for the nurse. Therefore, the work process of the SHE nursing team shall be reviewed, to include the provision of intermediate and minimum care to patients ${ }^{(14)}$.

Thus, prioritizing is an important tool in the nurse's work process in the SHE as it is necessary to adapt the physical and human resources available to the fluctuating demand of patients who have varying levels of complexity and need for care. However, coping strategies shall be discussed to avoid neglect of care and incomplete care.

The third instrument used by nurses is related to physical instruments, which assist in their work performance, providing a complete view of patients and their care needs, contributing to the control of tasks performance and for the patients'safety. The main instruments mentioned were shift change report, care map, and patient identification devices.

The printed shift change report assists the nurse in locating and identifying the severity and volume of patients, as well as their care needs. Moreover, the instrument contributes to communication, facilitating the shift change so that no important information is missed. An adequate shift change requires commitment from the team for a safe continuity of care; thus, the activity shall encompass all the information necessary for this continuity, such as problems, treatment, and nursing observations ${ }^{(24)}$.

To assist in the fulfillment of tasks, some professionals reported the use of a care map, which helps them in the organization of care and management activities. This result corroborates the findings of previous research, which also evidenced the use of devices such as lists with reminders to offer water and food to patients or to warn about the need for reassessment to improve patient safety ${ }^{(22)}$.
The ability to perform multiple tasks is a characteristic of emergency care, and it is imperative that the professional realizes this and is able to deal with it ${ }^{(10,11,25)}$. The use of these instruments becomes important, since the intense work routine and the attendance to life-limiting situations shift the focus from long-term care, making many inpatients' needs go unnoticed by nurses in care planning. Similarly, a systematic review of patient safety incidents in emergency services highlights the importance of instruments for standardization and division of tasks to improve the organization and management of work in these locations ${ }^{(26)}$.

Patient identification is perceived as essential for their safety, due to the difficulty in finding them due to the constant need to move stretchers. This is a problem that impairs patient safety ${ }^{(22)}$, which is worsened by overcrowding that, along with inadequate structure of services, is recognized as a factor increasing the possibility of errors in the emergency service $^{(27)}$.

The environment in SHE is intense and unpredictable; this characteristic, associated with the permanence of a high number of hospitalized patients and with different levels of complexities, leads to the nurses being required to deal with multiple tasks and care demands. This way, nurses develop peculiar instruments to manage multiple tasks and provide adequate and comprehensive care to patients.

\section{CONCLUSION}

This study concludes that the instruments used by nurses in their work process at the emergency department are a set of attitudes and skills acquired as strategies for management, first of the multiple tasks, and then of the needs for care and adequacy of resources. These characteristics are peculiar to the work process of nurses in emergencies, resulting from the intense pace and complex work environment.

It is expected that this research findings will encourage nurses to continuously seek the development of clinical skills and managerial instruments to work in hospital emergencies, aiming to meet the needs of patients who remain in the service, as well as of those who arrive with urgent demands. Additionally, the need for further research on skills and instruments is highlighted.

\section{RESUMO}

Objetivo: Descrever os instrumentos utilizados pelos enfermeiros para a gestão do cuidado frente às demandas do serviço hospitalar de emergência. Método: Estudo qualitativo, com triangulação de dados advindos de entrevistas, grupo focal e documentos, realizado com enfermeiros de um Serviço Hospitalar de Emergência de um estado do sul do Brasil. Os dados foram submetidos à análise de conteúdo temática. Resultados: Participaram 17 enfermeiros. As categorias que emergiram deste estudo foram: visão do todo, definição de prioridades e instrumentos físicos. Esses instrumentos são utilizados pelos enfermeiros para gerenciar múltiplas tarefas e proporcionar um cuidado adequado aos pacientes com diferentes níveis de complexidade, diante de um processo de trabalho intenso e imprevisível em função da demanda constante de atendimento. Conclusão: Os instrumentos utilizados pelos enfermeiros em seu processo de trabalho são principalmente habilidades e atitudes desenvolvidas como estratégia de enfrentamento ao ritmo intenso e complexo ambiente de trabalho.

\section{DESCRITORES}

Enfermagem em Emergência; Processo de Enfermagem; Gestão em Saúde; Serviço Hospitalar de Emergência.

\section{RESUMEN}

Objetivo: Describir los instrumentos utilizados por los enfermeros para la gestión del cuidado en función de las demandas del servicio hospitalario de emergencias. Método: estudio cualitativo, con triangulación de datos provenientes de entrevistas, grupo focal y documentos, realizado con enfermeros de un Servicio Hospitalario de Emergencias de una provincia al sur de Brasil. Los datos 
fueron sometidos al análisis de contenido temático. Resultados: Participaron 17 enfermeros. Las clases que resultaron tras el estudio fueron: visión global, definición de prioridades e instrumentos físicos. Esos instrumentos son utilizados por los enfermeros para manejar múltiples tareas y proporcionar un cuidado adecuado a los pacientes con diferentes niveles de complejidad ante un proceso de trabajo intenso e imprevisible debido a la demanda constante de atendimiento. Conclusión: Los instrumentos utilizados por los enfermeros en su proceso de trabajo son principalmente habilidades y actitudes desarrolladas como estrategia de enfrentamiento al ritmo intenso y ambiente complejo de trabajo.

\section{DESCRIPTORES}

Enfermería de Urgencia; Proceso de Enfermería; Gestión en Salud; Servicio de Urgencia en Hospital.

\section{REFERENCES}

1. Sanna MC. Os processos de trabalho em enfermagem. Rev Bras Enferm. 2007;60(2):221-4. https://doi.org/10.1590/S003471672007000200018

2. Neves FG, Moraes JRMM, Morais RCM, Souza TV, Ciuffo LL, Oliveira ICS. Nursing work in pediatric emergency from the perspective of the companion. Esc Anna Nery. 2016;20(3):e20160063. https://doi.org/10.5935/1414-8145.20160063

3. Barreto MS, Teston EF, Miranda JG, Arruda GO, Valsecchi EASS, Marcon SS. Perception of the nursing staff about the nurse's role in the emergency service. Rev Rene. 2015;16(6):833-41. http://dx.doi.org/10.15253/2175-6783.2015000600009

4. Montezeli JH, Peres AM, Bernardino E. Challenges for mobilization of management skills by nurses in emergency room. Ciênc Cuid Saúde. 2014;13(1):137-44.

5. Chen LC, Lin CC, Han CY, Hsieh CL, Wu CJ, Liang HF. An interpretative study on nurses' perspectives of working in an overcrowded Emergency Department in Taiwan. Asian Nurs Res. 2018;12(1):62-8. http://dx.doi.org/10.1016/j.anr.2018.02.003

6. Santos JLG, Menegon FHA, De Pin SB, Erdmann AL, Oliveira RJT, Costa IAP. The nurse's work environment in a hospital emergency service. Rev Rene. 2017;18(2):195-203. https://doi.org/10.15253/2175-6783.2017000200008

7. Hausmann M, Peduzzi M. Articulação entre as dimensões gerencial e assistencial do processo de trabalho do enfermeiro. Texto Contexto Enferm. 2009;18(2):258-65. https://doi.org/10.1590/S0104-07072009000200008

8. Mororó DDS, Enders BC, Lira ALBC, Silva CMB, Menezes RMP. Concept analysis of nursing care management in the hospital context. Acta Paul Enferm. 2017;30(3):323-32. http://dx.doi.org/10.1590/1982-0194201700043

9. Minayo MCS. O desafio do conhecimento: pesquisa qualitativa em saúde. 14 ed. São Paulo: Hucitec; 2014.

10. Forsberg HH, Athlin AM, Schwarz UT. Nurses' perceptions of multitasking in the emergency department: effective, fun and unproblematic (at least for me) - a qualitative study. Int Emerg Nurs. 2015;23(2):59-64. http://dx.doi.org/10.1016/j.ienj.2014.05.002

11. Person J, Spiva L, Hart P. The culture of an emergency department: an ethnographic study. Int Emerg Nurs. 2013;21(4):222-7. http://dx.doi. org/10.1016/j.ienj.2012.10.001

12. Van Der Linden MC, Khursheed M, Hooda K, Pines JM, Van Der Linden N. Two emergency departments, 6000 km apart: differences in patient flow and staff perceptions about crowding. Int Emerg Nurs. 2017;35:30-6. http://dx.doi.org/10.1016/j.ienj.2017.06.002

13. Santos JLG, Lima MADS, Pestana AL, Colomé ICS, Erdmann AL. Strategies used by nurses to promote teamwork in na emergency room. Rev Gaúcha Enferm. 2016;37(1):e50178. http://dx.doi.org/10.1590/1983-1447.2016.01.50178

14. Ohara R, Melo MRAC, Laus AM. Caracterização do perfil assistencial dos pacientes adultos de um pronto socorro. Rev Bras Enferm. 2010;63(5):749-54. http://dx.doi.org/10.1590/S0034-71672010000500009

15. Paixão TCR, Campanharo CRV, Lopes MCBT, Okuno MFP, Batista REA. Nursing staff sizing in the emergency room of a university hospital Rev Esc Enferm USP. 2015;49(3):481-7. http://dx.doi.org/10.1590/S0080-623420150000300017

16. Burström L, Starrin B, Engström M-L, Thulesius H. Waiting management at the emergency department: a grounded theory study. BMC Health Serv Res. 2013;13(1):1-10. http://dx.doi.org/10.1186/1472-6963-13-95

17. Bugs TV, Rigo DFH, Bohrer CD, Borges F, Oliveira JLC, Tonini NS. Dificuldades do enfermeiro no gerenciamento da unidade de prontosocorro hospitalar. Rev Enferm UFSM. 2017;7(1):90-9. http://dx.doi.org/10.5902/2179769223374

18. Ghezeljeh TN, Gharasoflo S, Haghani S. The relationship between missed nursing care and teamwork in emergency nurses: a predictive correlational study. Nurs Pract Today. 2021;8(2):103-12. https://doi.org/10.18502/npt.v8i2.5121

19. Santos JLG, Lima MADS. Gerenciamento do cuidado: ações dos enfermeiros em um serviço hospitalar de emergência. Rev Gaúcha Enferm. 2011;32(4):695-702. http://dx.doi.org/10.1590/S1983-14472011000400009

20. Johansen ML, O’Brien JL. Decision making in nursing practice: a concept analysis. Nurs Forum. 2016;51(1):40-8. http://doi.org/10.1111/ nuf.12119

21. Cardoso LS, Martins CF, Rosa LS, Passos JC, Cezar-Vaz MR. O pensar da enfermagem no serviço de urgência e emergência intra-hospitalar. J Nurs UFPE On line. 2016;10(12):4524-31. https://doi.org/10.5205/1981-8963-v10i12a11519p4524-4531-2016

22. Reay G, Rankin JA, Then KL. Momentary fitting in a fluid environment: a grounded theory of triage nurse decision making. Int Emerg Nurs. 2016;26:8-13. http://dx.doi.org/10.1016/j.ienj.2015.09.006

23. Eriksson J, Gellerstedt L, Hilleras P, Craftman AG. Registered nurses' perceptions of safe care in overcrowded emergency departments. J Clin Nurs. 2018;27(5-6):e1061-7. http://dx.doi.org/ 10.1111/jocn.14143

24. Sanjuan-Quiles A, Hernández-Ramón M, Juliá-Sanchis R, García-Aracil N, Castejón-de la Encina ME, Perpiñá-Galvañ J. Handover of patients from Prehospital Emergency Services to Emergency Departments: a qualitative analysis based on experiences of nurses. J Nurs Care Qual. 2019;34(2):169-74. https://doi.org/10.1097/NCQ.0000000000000351 
25. Rabelo SK, Lima SBS, Santos JLG, Costa VZ, Reisdorfer E, Santos TM, et al. Processo de trabalho do enfermeiro em um serviço hospitalar de emergência. Rev Bras Enferm. 2020;73(5):e20180923. https://doi.org/10.1590/0034-7167-2018-0923

26. Amaniyan S, Faldaas BO, Logan PA, Vaismoradi M. Learning from patient safety incidents in the Emergency Department: a systematic review. J Emerg Med. 2020;58(2):234-44. https://doi.org/10.1016/j.jemermed.2019.11.015

27. Bampi R, Lorenzini E, Krauzer IM, Ferraz L, Silva EF, Dall'Agnol CM. Perspectivas da equipe de enfermagem sobre a segurança do paciente em unidade de emergência. J Nurs UFPE On line. 2017;11(2):584-90. https://doi.org/10.5205/1981-8963-v11i2a11977p584-590-2017 